\title{
Extracorporeal membrane oxygenation for postoperative complications in general thoracic surgery: a ten-year experience of a university referral centre
}

\author{
Guido Di Gregorio ${ }^{1}$, Nicolò Sella ${ }^{2}$, Pia Ferrigno ${ }^{3}$, Annalisa Boscolo ${ }^{1}$, Demetrio Pittarello ${ }^{1}$, Federico Rea ${ }^{3}$, \\ Paolo Navalesi ${ }^{1,2}$, Andrea Dell'Amore ${ }^{3}$ \\ ${ }^{1}$ Anaesthesia and Intensive Care Unit, Padua University Hospital, Padua, Italy; ${ }^{2}$ Department of Medicine (DIMED), Padua University Hospital, \\ Padua, Italy; ${ }^{3}$ Thoracic Surgery and Lung Transplantation Unit, Department of Cardio-Thoracic and Vascular Sciences and Public Health, Padua \\ University Hospital, Padua, Italy \\ Contributions: (I) Conception and design: G Di Gregorio, N Sella; (II) Administrative support: None; (III) Provision of study materials or patients: F \\ Rea, P Navalesi; (IV) Collection and assembly of data: N Sella, P Ferrigno, A Boscolo; (V) Data analysis and interpretation: N Sella, A Dell'Amore; (VI) \\ Manuscript writing: All authors; (VII) Final approval of manuscript: All authors. \\ Correspondence to: Guido Di Gregorio, MD, PhD. Via V. Gallucci 13, 35125 Padova, Italy. Email: guidodigre@gmail.com.
}

Background: Extracorporeal membrane oxygenation (ECMO) is a rescue therapy that supports gas exchange and hemodynamic parameters in patients with severe respiratory or cardiac failure. In the last ten years, a significant increment in the use of ECMO has been occurred in thoracic surgery for lung transplant, but little is known about the role of ECMO to face severe complications after general thoracic surgery. This study aims: (I) to investigate the incidence of postoperative adverse events, requiring ECMO support, after general thoracic surgery, and (II) to evaluate the intensive care unit (ICU) and hospital survival in patients who received ECMO after general thoracic surgery.

Methods: We retrospectively reviewed the ECMO registry data on patients who received ECMO after general thoracic surgery at Padua University Hospital (Italy) from January 1, 2010 to January 1, 2020. Exclusion criteria were: (I) postoperative prolongation of intraoperative extracorporeal life support, (II) lung transplantation, (III) concomitant heart surgery.

Results: During a ten years period, among 6,837 patients who underwent general thoracic surgery procedures, $7(0.1 \%)$ required ECMO support due to severe postoperative adverse events [acute respiratory distress syndrome (ARDS) in $42.9 \%$ of cases and cardiac failure and haemodynamic instability in $57.1 \%$ of cases]. Among these patients, $42.8 \%$ died in ICU. All patients, discharged alive from ICU, survived to hospital discharge. After 1 year follow-up, only $33.3 \%$ of patients was alive.

Conclusions: ECMO support after general thoracic surgery is a lifesaving rescue therapy for the treatment of postoperative cardio-respiratory adverse events in 'complicated' clinical scenarios not manageable with conventional medical approaches. In this specific study cohort, the use of postoperative ECMO was associated with an acceptable survival rate.

Keywords: Extracorporeal membrane oxygenation (ECMO); thoracic surgery; acute respiratory distress syndrome (ARDS); cardiac failure; postoperative complications

Received: 28 July 2020; Accepted: 02 September 2020; Published: 25 November 2020.

doi: $10.21037 /$ ccts-20-132

View this article at: http://dx.doi.org/10.21037/ccts-20-132 


\section{Introduction}

Patients undergoing general thoracic surgery are at high risk to develop major postoperative complications, whose incidence and severity are influenced by several factors, such as the medical comorbidities and the performance status at hospital admission, the disease requiring surgery, and the physiologic impact of the procedure (1). Acute respiratory failure (ARF) with acute respiratory distress syndrome (ARDS) and adverse cardiovascular events are the most serious complications after general thoracic surgery, and both events are associated with increased morbidity and mortality $(2,3)$. Extracorporeal membrane oxygenation (ECMO) is a lifesaving technique that supports gas exchange or hemodynamic parameters in patients with severe respiratory or cardiac failure, and thus it can be a rescue therapy for patients developing major complications after general thoracic surgery. In the recent years, a significant increase in the utilization of ECMO has occurred in thoracic surgery, as a growing numbers of centres are using this lifesaving technique mostly in the perioperative period of lung transplantation, either to bridge the patient to transplant or to prevent and treat right ventricular failure and primary graft dysfunction (4). However, little is known about the role of ECMO after general thoracic surgery.

Herein, we present the experience of ECMO after general thoracic surgery in a University Referral Hospital. Our aims are: (I) to investigate the incidence of postoperative adverse events requiring ECMO support after general thoracic surgery, and (II) to evaluate the intensive care unit (ICU) and hospital survival in patients who received ECMO after general thoracic surgery. We present the following article in accordance with the STROBE reporting checklist (available at https://ccts.amegroups. com/article/view/10.21037/ccts-20-132/rc).

\section{Methods}

We retrospectively reviewed the ECMO registry data on patients who received veno-venous (VV) or veno-arterial (VA) ECMO after general thoracic surgery at Padua University Hospital (Padua, Italy), considering a period of ten years, from January 1, 2010 to January 1, 2020.

Inclusion criteria were: (I) age $>18$ years, (II) ECMO support as treatment of postoperative complications, (III) general thoracic surgery procedures during the hospital stay. Patients were considered eligible for ECMO according to the Extracorporeal Life Support Organization (ELSO) guidelines. VV ECMO was chosen if the patient had a ratio of partial pressure of arterial oxygen to the fraction of inspired oxygen $\left(\mathrm{PaO}_{2} / \mathrm{FiO}_{2}\right)<100$ on $\mathrm{FiO}_{2}>0.9$ and/or Murray score 3-4 and/or carbon-dioxide $\left(\mathrm{CO}_{2}\right)$ retention, despite optimal care on mechanical ventilation (5). VA ECMO was initiated if hypotension and low cardiac output caused insufficient tissue perfusion, despite adequate volume administration, inotropes and vasoconstrictors (6).

Exclusion criteria were: (I) postoperative prolongation of intraoperative extracorporeal life support, (II) lung transplantation, (III) concomitant heart surgery.

The data collected included: age, sex, body mass index, past medical history, preoperative surgical diagnosis, general thoracic surgery procedure, reason for ECMO therapy, time of ECMO initiation, length of ECMO support and invasive mechanical ventilation (IMV), complications during ECMO, ICU and hospital length of stay, in-ICU and in-hospital survival, 1 year and long term follow-up.

The study was conducted in accordance with the Declaration of Helsinki (as revised in 2013). The retrospective historical nature of the study waived the need for ethical approval. Informed consent for data publication was routinely obtained from each patient at the time of hospital admission.

\section{Results}

From January 1, 2010 to January 1, 2020, 6,837 adult patients underwent general thoracic surgery at our Thoracic Surgery Unit. Surgical procedures included tracheal surgery and resections of lung, mediastinal neoplasms or chest wall malignancies. Among them, 7 patients required ECMO support postoperatively, thus counting for $0.1 \%$ incidence of ECMO use after general thoracic surgery over a ten years period.

Patients' preoperative demographic characteristics are listed in Table 1. The average age was 60 years (range, $57-$ 67 years). The average BMI was $26.7 \mathrm{~kg} / \mathrm{m}^{2}$ (range, $22.7-$ $32.9 \mathrm{~kg} / \mathrm{m}^{2}$ ). The most frequent comorbidities included arterial hypertension, heart diseases, and diabetes. The primary surgical diagnoses were non-small cell lung cancer in $3(42.9 \%)$ patients, malignant pleural mesothelioma in $3(42.9 \%)$ patients, and lung metastases from colon cancer in $1(14.2 \%)$ subject. Thoracic surgical procedures included 2 (28.6\%) pneumonectomies, 2 (28,6\%) pleuro-pneumonectomies with pleural decortications and diaphragmatic resection, 2 (28.6\%) bilateral lung lobectomies, and $1(14.2 \%)$ pleurectomy with pleural 
Table 1 Patient demographics

\begin{tabular}{|c|c|c|c|c|c|c|c|}
\hline ID & $\begin{array}{c}\text { Age } \\
\text { (years) }\end{array}$ & Sex & $\begin{array}{c}\text { BMI } \\
\left(\mathrm{kg} / \mathrm{m}^{2}\right)\end{array}$ & $\begin{array}{l}\text { Surgical } \\
\text { diagnosis }\end{array}$ & $\begin{array}{l}\text { Preop } \\
\text { CRT }\end{array}$ & Comorbidities & Surgical procedure \\
\hline 1 & 59 & M & 27.8 & $\begin{array}{l}\text { NSCLC } \\
\text { relapse }\end{array}$ & Yes & $\begin{array}{l}\text { Arterial hypertension, atrial } \\
\text { fibrillation, chronic ischemic } \\
\text { heart disease, history of right } \\
\text { lung lobectomy for NSCLC }\end{array}$ & $\begin{array}{c}\text { Right thoracotomy: completion of right } \\
\text { pneumonectomy + superior vena cava } \\
\text { resection + tracheoplasty }\end{array}$ \\
\hline 3 & 58 & M & 29.4 & NSCLC & No & Congenital deafness & $\begin{array}{l}\text { Right thoracotomy: right } \\
\text { pneumonectomy }\end{array}$ \\
\hline 4 & 58 & M & 23.7 & $\begin{array}{l}\text { Lung } \\
\text { metastases } \\
\text { from colon } \\
\text { cancer }\end{array}$ & Yes & $\begin{array}{l}\text { Arterial hypertension, } \\
\text { paroxysmal supraventricular } \\
\text { tachycardia, colon cancer }\end{array}$ & $\begin{array}{l}\text { Right VATS: right lower lobectomy. Left } \\
\text { thoracotomy: left lower lobectomy }\end{array}$ \\
\hline 6 & 61 & $\mathrm{~F}$ & 32.9 & $\begin{array}{l}\text { Malignant } \\
\text { pleural } \\
\text { mesothelioma }\end{array}$ & Yes & $\begin{array}{c}\text { Paroxysmal supraventricular } \\
\text { tachycardia, type } 2 \text { diabetes } \\
\text { mellitus }\end{array}$ & $\begin{array}{l}\text { Right thoracotomy: right pleurectomy/ } \\
\text { decortication + right hemidiaphragm } \\
\text { resection + right pneumonectomy }\end{array}$ \\
\hline 7 & 57 & M & 23.2 & $\begin{array}{l}\text { Malignant } \\
\text { pleural } \\
\text { mesothelioma }\end{array}$ & Yes & $\begin{array}{l}\text { Aortic valve replacement, } \\
\text { history of non-Hodgkin } \\
\text { lymphoma and colon cancer }\end{array}$ & $\begin{array}{l}\text { Left thoracotomy: left pleurectomy/ } \\
\text { decortication + left hemidiaphragm } \\
\text { resection + left pneumonectomy }\end{array}$ \\
\hline
\end{tabular}

ID, patient identification number. BMI, body mass index; preop CRT, preoperative chemo-radiotherapy; M, male; F, female; NSCLC, non small cell lung cancer; VATS, video-assisted thoracoscopy.

decortication and diaphragmatic resection.

ECMO characteristics are reported in Table 2. The average time between surgery and ECMO placement was 8.4 days (range, $0-20$ days). The cause for ECMO initiation was ARDS in $3(42.9 \%)$ cases and cardiac failure, followed by haemodynamic instability, in $4(57.1 \%)$ patients. The majority of patients received VA ECMO (85.8\%), except for one. The only patient supported by VV ECMO was managed with awake strategy for 2 days before requiring endotracheal intubation followed by IMV. ECMO-related complications occurred in $2(28.6 \%)$ cases.

Patients' clinical outcomes are listed in Table 3. The average length of time on ECMO was 5 days (range, $1-11$ days). Six patients out of $7(85.8 \%)$ were successfully weaned from extracorporeal support and $4(57.1 \%)$ from IMV. The average length of IMV was 12 days (range, 3-25 days). ICU survival rate was $57.1 \%$, and the average ICU length of stay was 16 days (range, 8-25 days). All patients discharged alive from ICU survived to hospital discharge. The average length of hospital stay was 38 days (range, 18-71 days). One-year survival was equal to $33.3 \%$ and, considering only patients discharged alive from hospital, the overall survival was around 29 months (range, 5-69 months).

\section{Discussion}

Postoperative complications requiring ECMO support after general thoracic surgery are usually associated to high mortality. In our experience, during a period of 10 years, $0.1 \%$ of patients who underwent general thoracic surgery developed severe postoperative adverse events requiring ECMO treatment. Among these patients, more than $40 \%$ died in ICU and only $33.3 \%$ was still alive after 1 year.

To our best knowledge, few investigations were previously published on the use of ECMO after general thoracic surgery and most of them were based on quite small sample sizes. Indeed, excluding case-series with less than 3 patients, only seven studies remain to consider.

The first study searched the ELSO registry data from 
Table 2 ECMO characteristics

\begin{tabular}{|c|c|c|c|c|c|}
\hline ID & Cause for ECMO & $\begin{array}{l}\text { Surgery to ECMO } \\
\text { time (days) }\end{array}$ & ECMO type & ECMO complications & Other complications \\
\hline 1 & Cardiogenic shock & 0 & VA & No & Acute kidney injury \\
\hline 2 & ARDS & 12 & VV & No & Atrial fibrillation \\
\hline 3 & ARDS & 5 & VA & No & Deep vein thrombosis \\
\hline 5 & Cardiac arrest & 7 & VA & $\begin{array}{l}\text { Venous cannula displacement } \\
\text { into the right ventricle }\end{array}$ & Atrial fibrillation, right hemothorax \\
\hline 6 & ARDS & 20 & VA & $\begin{array}{l}\text { Harlequin syndrome, bleeding } \\
\text { from cannula insertion sites }\end{array}$ & $\begin{array}{l}\text { Right hemothorax, ventricular } \\
\text { arrhythmia }\end{array}$ \\
\hline
\end{tabular}

ID, patient identification number. ECMO, extracorporeal membrane oxygenation; ARDS, acute respiratory distress syndrome; VA, venoarterial; VV, veno-venous; CRRT, continuous renal replacement therapy.

Table 3 Clinical outcomes

\begin{tabular}{|c|c|c|c|c|c|c|c|c|c|}
\hline ID & $\begin{array}{l}\text { Length } \\
\text { of ECMO } \\
\text { (days) }\end{array}$ & $\begin{array}{c}\text { Weaning } \\
\text { from ECMO }\end{array}$ & $\begin{array}{l}\text { Length of } \\
\text { IMV (days) }\end{array}$ & $\begin{array}{l}\text { Weaning } \\
\text { from IMV }\end{array}$ & $\begin{array}{l}\text { ICU length } \\
\text { of stay } \\
\text { (days) }\end{array}$ & $\begin{array}{c}\text { ICU } \\
\text { survival }\end{array}$ & $\begin{array}{l}\text { Hospital } \\
\text { length of } \\
\text { stay (days) }\end{array}$ & $\begin{array}{l}\text { Hospital } \\
\text { survival }\end{array}$ & $\begin{array}{l}\text { Overall } \\
\text { survival* }^{*} \\
\text { (months) }\end{array}$ \\
\hline 2 & 9 & Yes & 14 & Yes & 17 & Yes & 64 & Yes & 69 \\
\hline 3 & 6 & Yes & 25 & No & 25 & No & 30 & No & - \\
\hline 5 & 2 & Yes & 4 & Yes & 14 & Yes & 36 & Yes & 14 \\
\hline 6 & 11 & No & 18 & No & 24 & No & 31 & No & - \\
\hline 7 & 4 & Yes & 8 & Yes & 11 & Yes & 71 & Yes & 5 \\
\hline
\end{tabular}

*, overall survival is calculated from ECMO implantation in patients survived to hospital discharged. ID, patient identification number; ECMO, extracorporeal membrane oxygenation; IMV, invasive mechanical ventilation; ICU, intensive care unit; FU, follow-up.

2007 to 2010 and found 21 patients who underwent ECMO for tracheal stenosis, of whom 5 were on VV ECMO and 16 on VA ECMO (7). Although the authors do not specify whether ECMO support was initiated preoperatively or postoperatively, they reported a survival rate of $57 \%$.

The second study analysed VV ECMO for postoperative ARDS. Among 69 patients requiring extracorporeal support for ARDS after surgical procedures during a five years period, $14(20 \%)$ patients underwent general thoracic surgery and only $1(7 \%)$ survived to hospital discharged (8). Interestingly, patients undergone cardiothoracic surgery showed significantly lower survival rates than those who underwent other operations.

The third study presented 10 patients treated with awake ECMO for postoperative ARDS with a survival rate of $80 \%$ (9). In this case-series, 7 (70\%) patients experienced thoracic surgery and then developed ARDS either due to postoperative pneumonia (4 patients) or to massive haemoptysis (3 patients).

A more recent retrospective study recorded an incidence of $0.2 \%$, over 8 years, of ECMO placement after general thoracic surgery. Specifically, 29 patients required postoperative extracorporeal life support among 17,185 adults who underwent general thoracic surgical procedures (10). 
The indications for ECMO were respiratory failure in $82.8 \%$ of cases, and hemodynamic instability in $17.2 \%$ of cases. These authors reported a survival to decannulation and a survival to hospital discharge of $34.5 \%$ and $24.1 \%$, respectively. Notably, prolonged time between surgery and ECMO placement (>2 days) was a significant risk factor for hospital mortality.

In another recent study, among 232 adult patients who underwent pneumonectomy during a 6 years period, 8 patients (3.4\%) required postoperative VV ECMO support due to severe ARDS. Four patients out of 8 survived to hospital discharged, increasing the expected survival rate, based on the Sequential Organ Failure Assessment (SOFA) score, from $20 \%$ to $50 \%$ before ECMO insertion (11).

Another retrospective review of patients who received extracorporeal support after thoracic surgery over 5 years period identified 6 patients placed on VV ECMO and 2 patients placed on VA ECMO (12). Among these 8 patients, $4(50 \%)$ were successfully weaned from extracorporeal support and 3 (37\%) survived to hospital discharge. Remarkably, this study demonstrated that ECMO after general thoracic surgery costs significantly more than in other subgroups of patients, with an average total hospital charge of $\$ 1,053,551$ each patient.

Finally, a study on 20 postoperative ECMO applied in non-cardiotomy patients counted 10 cases who underwent general thoracic surgery over an eleven years period. The indications for extracorporeal support were respiratory failure $(80 \%)$ and cardiogenic shock $(20 \%)$ with a length of time between surgery to ECMO of 4 days and ECMO length of time of 8 days (13). The survival to hospital discharge was $60 \%$.

In summary, the survival rates reported in these studies are extremely variable, ranging from $7 \%$ to $70 \%$. These unclear and heterogeneous results may be ascribable to severe disparities in study design and to heterogeneous surgical populations with different pulmonary pathologies, comorbidities and surgical procedures. Indeed, the survival rate for ECMO patients differs significantly between studies, ranging from $29 \%$ at hospital discharge in adult patients requiring VA ECMO for cardiac arrest unresponsive to conventional cardiopulmonary resuscitation (14), to $65 \%$ at 60 days in adult patients supported for severe ARDS (15), and up to $95 \%$ at 30 days in adult patients prophylactically treated with VA ECMO after bilateral lung transplant (16).

Patients undergoing general thoracic surgery procedures are mainly affected by oncological diseases and present often numerous comorbidities, which may impair their performance status and cause a significant decline in multiple physiological systems (17). Moreover, frailty is a frequent condition in patients who underwent thoracic surgery, and more than $69 \%$ of candidates usually have more than one frailty trait (18). This finding could justify the lower survival rate registered among patients supported with ECMO after general thoracic surgery compared to other ECMO populations. Notably, in our experience, although all the patients had thoracic malignancies and $72 \%$ of them underwent preoperative oncological treatments (including chemotherapy and radiotherapy), all patients, except 1, were successfully weaned from ECMO, and only $28 \%$ of the patients experienced ECMO-related complications.

When patients develop severe cardiopulmonary complications after general thoracic surgery not manageable with conventional therapy, ECMO appears to be a valid option in order to allow multi-organ recovery and to make better clinical decisions. Indeed, these patients should not be excluded a priori from extracorporeal support. Even if ECMO is an invasive and very resource-consuming treatment, for each case a multidisciplinary risk/benefit balance should be evaluated before ECMO initiation, assessing not only the preoperative comorbidities, but also the type of surgery performed, the patient's postoperative clinical conditions, the timing of the call for initiation of ECMO, and the previously expressed wishes of the patient. Extracorporeal support should be offered if there is a reasonably chance that ECMO will achieve the desired outcome and if the patient would likely benefit from it in a middle-long term perspective (19).

\section{Conclusions}

ECMO support after general thoracic surgery is a lifesaving rescue option for the treatment of postoperative cardiorespiratory complications in the rare cases $(0.1 \%)$ that cannot be managed with conventional therapies. In this highly selected population, postoperative ECMO use is associated with acceptable survival rate (ICU survival rate $57.1 \%$, and 1 -year survival rate $33.3 \%$ ). Further studies, with larger multicentric sample sizes, are needed to determine the effectiveness of ECMO application after general thoracic surgery, and to establish safe prognostic criteria for identifying patients who mostly benefit from a valid postoperative ECMO support. 


\section{Acknowledgments}

Funding: None.

\section{Footnote}

Provenance and Peer Review: This article was commissioned by the editorial office, Current Challenges in Thoracic Surgery for the series "Mechanical Extracorporeal CardioRespiratory Supports in General Thoracic Surgery". The article has undergone external peer review.

Reporting Checklist: The authors have completed the STROBE reporting checklist. Available at https://ccts. amegroups.com/article/view/10.21037/ccts-20-132/rc

Data Sharing Statement: Available at https://ccts.amegroups. com/article/view/10.21037/ccts-20-132/dss

Conflicts of Interest: All authors have completed the ICMJE uniform disclosure form (available at https://ccts. amegroups.com/article/view/10.21037/ccts-20-132/coif). The series "Mechanical Extracorporeal Cardio-Respiratory Supports in General Thoracic Surgery" was commissioned by the editorial office without any funding or sponsorship. ADA served as the unpaid Guest Editor of the series. The authors have no other conflicts of interest to declare.

Ethical Statement: The authors are accountable for all aspects of the work in ensuring that questions related to the accuracy or integrity of any part of the work are appropriately investigated and resolved. The study was conducted in accordance with the Declaration of Helsinki (as revised in 2013). The retrospective historical nature of the study waived the need for ethical approval. Informed consent for data publication was routinely obtained from each patient at the time of hospital admission.

Open Access Statement: This is an Open Access article distributed in accordance with the Creative Commons Attribution-NonCommercial-NoDerivs 4.0 International License (CC BY-NC-ND 4.0), which permits the noncommercial replication and distribution of the article with the strict proviso that no changes or edits are made and the original work is properly cited (including links to both the formal publication through the relevant DOI and the license). See: https://creativecommons.org/licenses/by-nc-nd/4.0/.

\section{References}

1. Van Haren RM, Mehran RJ, Mena GE, et al. Enhanced Recovery Decreases Pulmonary and Cardiac Complications After Thoracotomy for Lung Cancer. Ann Thorac Surg 2018;106:272-9.

2. Kometani T, Okamoto T, Yoshida S, et al. Acute respiratory distress syndrome after pulmonary resection. Gen Thorac Cardiovasc Surg 2013;61:504-12.

3. Keshava HB, Boffa DJ. Cardiovascular Complications Following Thoracic Surgery. Thorac Surg Clin 2015;25:371-92.

4. Ius F, Tudorache I, Warnecke G. Extracorporeal support, during and after lung transplantation: the history of an idea. J Thorac Dis 2018;10:5131-48.

5. ELSO Adult Respiratory Failure Guidelines. Version 1.4, August 2017.

6. ELSO Adult Cardiac Failure Supplement to the ELSO General Guidelines. Version 1.3, December 2013.

7. Raake J, Johnson B, Seger B, et al. Extracorporeal membrane oxygenation, extubation, and lung-recruitment maneuvers as rescue therapy in a patient with tracheal dehiscence following slide tracheoplasty. Respir Care 2011;56:1198-202.

8. Seo DJ, Yoo JS, Kim JB, et al. Venovenous Extracorporeal Membrane Oxygenation for Postoperative Acute Respiratory Distress Syndrome. Korean J Thorac Cardiovasc Surg 2015;48:180-6.

9. Yeo HJ, Cho WH, Kim D. Awake extracorporeal membrane oxygenation in patients with severe postoperative acute respiratory distress syndrome. J Thorac Dis 2016;8:37-42.

10. Lee H, Cho YH, Chang HW, et al. The Outcome of Extracorporeal Life Support After General Thoracic Surgery: Timing of Application. Ann Thorac Surg 2017;104:450-7.

11. Reeb J, Olland A, Pottecher J, et al. Extracorporeal Membrane Oxygenation for Acute Respiratory Distress Syndrome After Pneumonectomy. Ann Thorac Surg 2017;103:881-9.

12. Harris DD 2nd, Saha SP. Extracorporeal membrane oxygenation as a rescue measure after thoracic surgery. Asian Cardiovasc Thorac Ann 2018;26:203-6.

13. Lang H, Milanuk M, Brady J, et al. Outcomes of noncardiotomy patients requiring postoperative extracorporeal membrane oxygenation. J Card Surg 2020;35:1444-51. 
14. Extracorporeal Life Support Organization. ECLS Registry Report Inter- national Summary 2020. Available online: https://www.elso.org/Registry/Statistics/ InternationalSummary.aspx

15. Combes A, Hajage D, Capellier G, et al. Extracorporeal Membrane Oxygenation for Severe Acute Respiratory Distress Syndrome. N Engl J Med 2018;378:1965-75.

16. Hoetzenecker K, Schwarz S, Muckenhuber M, et al. Intraoperative extracorporeal membrane oxygenation and the possibility of postoperative prolongation improve survival in bilateral lung transplantation. J Thorac

doi: $10.21037 /$ ccts-20-132

Cite this article as: Di Gregorio G, Sella N, Ferrigno P, Boscolo A, Pittarello D, Rea F, Navalesi P, Dell'Amore A. Extracorporeal membrane oxygenation for postoperative complications in general thoracic surgery: a ten-year experience of a university referral centre. Curr Chall Thorac Surg 2020;2:36.
Cardiovasc Surg 2018;155:2193-206.e3.

17. Castillo M. An overview of perioperative considerations in elderly patients for thoracic surgery: demographics, risk/ benefit, and resource planning. Curr Opin Anaesthesiol 2018;31:1-5.

18. Beckert AK, Huisingh-Scheetz M, Thompson K, et al. Screening for Frailty in Thoracic Surgical Patients. Ann Thorac Surg 2017;103:956-61.

19. Abrams D, Curtis JR, Prager KM, et al. Ethical Considerations for Mechanical Support. Anesthesiol Clin 2019;37:661-73. 